\title{
МОРСЬКА ДОКТРИНА УКРАЇНИ: ЕВОЛЮЦІЙНИЙ АСПЕКТ ПРОЦЕСУ ФОРМУВАННЯ
}

Кузнєцов С. С.

\begin{abstract}
У науковій статті досліджено еволюційний аспект процесу формування доктрини (доктринотворення) та Морської доктрини України, зокрема. Виокремлюються стадії доктринотворення та констатується його циклічність. Першою визначено стадію розвитку витоків (джерел, підстав) доктринотворення. Другою - стадію наукового пізнання, третьою - стадію суспільної доктриналізації, четвертою - стадію державної доктриналізації - надання певній доктрині статусу джерела права у формі правового акта. Класифіковано складники зазначених стадій.

Ключові слова: доктринотворення, доктриналізація, розвиток, стадії та етапи розвитку, Морська доктрина України.
\end{abstract}

В научной статье исследован эволюционный аспект процесса формирования доктрины (доктринообразование) и Морской доктрины Украины, в частности. Выделяются стадии доктринообразования и констатируется его цикличность. Первой стадией определена стадия развития истоков (источников, оснований) доктринообразования. Второй - стадию научного познания, третьей - стадию общественной доктринализации, четвертой - стадию государственной доктринализации - предоставления определенной доктрине статуса источника права в форме правового акта. Классифицированы составляющие указанных стадий.

Ключевые слова: доктринообразование, доктринализация, развитие, стадии и этапы развития, Морская доктрина Украины.

Kuznietsov S. S. The Maritime Doctrine of Ukraine: the evolutionary aspect of the process of formation

The evolutionary aspect of the process of the doctrine formation (doctrine creation) and Maritime Doctrine of Ukraine, in particular, was investigated in the article. Understanding the concept of "doctrine creation" as a process of doctrine formation naturally leads the author to the conclusion that achieving the goal of the study involves the selection of stages as components of the doctrine process and steps as components of certain stages of the development of the object under study. Dividing doctrine creation into certain stages and steps, the author draws attention to the cyclical nature of the studied

(c) Кузнєцов С. С., 2020 development process. The first stage of the studied process the author defines as "the stage of the development of the beginnings (sources, bases) of doctrine creation". The certain steps are defined as the components of this stage, in particular: the step of the development of new activities in certain areas of social production; the step of the development of new technologies, methods, means of social production; the step of the development of new social relations; the emergence of certain legal acts - legal facts - the circumstances of objective social life, which became the basis for the relevant legal relations, etc. The author notes that the appearance of the relevant legal acts is associated with the bylaw activity of the Cabinet of Ministers of Ukraine on the formation of Maritime Doctrine of Ukraine. The second stage - "the stage of the scientific cognition" - is a stage associated with the cognitive activity of subjects that are involved independently (as subjects of professional and / or scientific activity), according to plans of scientific activity or at the request of competent state authorities (as subjects of the scientific activity in a certain field) to the cognition of the phenomena of social life in a certain field. As the components of this stage the author defines: the step of studying the manifestations (phenomena) of social existence (for legal doctrines - manifestations (phenomena) of state and legal reality); the step of identifying facts, trends, characteristics and problems related to certain manifestations (phenomena) of social existence (everyday cognition); the step of determining the object, subject, methods and objectives of the study, the step of analysis of information: statistical, analytical, empirical, etc., which is associated with the investigation of the chosen subject of the study; the step of identifying internal and external factors that have an impact (positive or negative) on the development of the object of the study; the step of elaboration and formulation of conclusions and proposals relating to the development of the object of the study; the step of objectification (documentation) of research results. The third stage - "the stage of social doctrinalization" - is a stage of recognition of research results by the scientific community. The steps of this stage are defined as following: the step of publication, discussion, testing of research results; the step of making a decision on the legalization of the results of the study and appeal to the competent public authorities and / or subjects of the right of legislative initiative (formation of a "legal motive"). The fourth stage - "the stage of state doctrinalization" - is a stage 
of legalization of research results - the stage of granting a certain doctrine the status of a source of law in the form of a legal act. This stage includes the steps of state recognition at the level of competent executive bodies and the steps of state recognition at the level of legislative power. As a result of the research, the author's definition of the concepts of "doctrine creation" as a process of doctrine formation and "doctrinalization" as a certain stage of the doctrine formation process was formulated. It is determined that doctrine creation is a process of development, which consists of a number of stages and steps that are part of the particular stages.

Key words: doctrine creation, doctrinalization, development process, stages and steps of development process, Maritime doctrine of Ukraine.

Постановка проблеми та іï актуальність. Сучасний етап державотворення України тісно пов'язаний із морським напрямом її внутрішньої та зовнішньої політики. На жаль, довгий час морська діяльність не визнавалась (свідомо чи несвідомо) іï пріоритетом, значення якого яскраво проявилось, починаючи із 2014 року та окупації суходольних та морських просторів України державою-агресором. I саме з того часу значно активізувались заклики до оновлення морського законодавства держави, прогальність та неефективність якого нарешті було об'єктивно визнано. А горезвісні наслідки неуваги до його оновлення стали причиною стабільно тяжкої ситуації з відновленням, захистом та підтриманням юрисдикції України у прибережних морських просторах. Лише через чотири роки після окупації акваторій України було оновлено програмний документ галузі - Морську доктрину на період до 2035 року, а з набранням чинності Постановою Кабінету Міністрів України від 18 грудня 2018 р. № 1108 «ро внесення змін до Морської доктрини України на період до 2035 року» [1] постало практичне завдання - завдання її реалізації. Якість та ефективність їі реалізації залежатиме від наукового обґрунтування форм, методів і напрямів діяльності компетентних органів виконавчої влади України у вказаній сфері, що $є$ науковим завданням. А розуміння процесуального характеру зазначеної діяльності ставить питання про необхідність насамперед наукового дослідження еволюційного аспекту процесу формування доктрини (доктринотворення) та Морської доктрини України на період до 2035 року, зокрема.

Аналіз останніх досліджень і публікацій. Для досягнення мети дослідження враховано наукові здобутки українських та іноземних вчених, як-от Т.В. Аверочкіна, С.В. Васильєв, Ю.В. Гаврюсов,
С.В. Ківалов, М.В. Кармаліта, Ю.М. Оборотов, В.С. Нерсесянц, Є.Ю. Полянський, І.В. Семеніхін, О.Ф. Скакун, П.М. Рабинович, та інших, що становлять емпіричну базу дослідження. Водночас зазначені автори у своїх розвідках здебільшого зупиняються на окремих аспектах творення правових доктрин або розглядають їх під обраним спеціальним кутом зору. А Морську доктрину України як відносно нове явище сучасної правової дійсності розглядають лише деякі з них, що зумовлює необхідність проведення теоретико-прикладних досліджень із метою вироблення надійного наукового базису оновлення діючого морського законодавства України.

Метою статті $\epsilon$ дослідження еволюційного аспекту процесу формування доктрини (доктринотворення) та Морської доктрини України, зокрема.

Виклад основного матеріалу. Загальнонаукову категорію, що позначається терміном «розвиток», необхідно розуміти як зміну (послідовні зміни - процес змін) матеріальних або ідеальних об'єктів. Процеси розвитку серед усіх інших виділяє їх незворотність, цілеспрямованість та закономірність. Наслідком процесів розвитку $\epsilon$ виникнення нового якісного стану об'єкта, що проявляється у зміні його стану та/або структури - виникнення, трансформація або зникнення елементів і зв'язків. Виділяють два основних типи розвитку: еволюція та революція. Водночас вивчення аспектів розвитку певних об'єктів, зокрема формування еволюційних уявлень про об'єкт, котрий розвивається, має самостійне значення [2, с. 537]. Щодо «процесів соціальних», то варто розуміти, що це послідовна зміна станів або рух елементів будь-якого соціального об'єкта. Такі процеси здійснюються під впливом внутрішніх та зовнішніх умов і спрямовані до певного стану певного соціального об'єкта. Кожний із процесів складається з декількох стадій, які відрізняються за змістом і засобами взаємозв'язку його складників, які визначають його спрямованість на цій стадії [3, с. 263-264]. Отже, об'єктом цього дослідження визначено доктринотворення процес формування доктрини взагалі та Морської доктрини України, зокрема. Предметом цього дослідження визначено еволюційний аспект процесу доктринотворення.

Оскільки в науці доводиться використовувати слова природної мови, властива їх невизначеність створює проблеми однакового розуміння і вживання понять, що виражаються за їх допомогою [4, с. 52]. Отже, вважаємо, що аналіз правових термінів має здійснюватися найперше з ураху- 
ванням положень лексикології про полісемію, тобто використання багатозначних слів чи словосполучень під час позначення одного й того ж поняття. Більшість слів можуть мати кілька значень у мовленні, як правило, в кожному конкретному випадку реалізується лише одне, зумовлене сполучуваністю й контекстом [5, с. 125-126). Наявність різних лексичних значень в одного й того ж слова відповідно до різних контекстів це полісемія [6, с. 8]. Водночас, незважаючи на семантичний зв'язок між значеннями полісемічного слова, всі його значення об'єднати в єдине не можна, адже кожне зі значень співвідноситься з різними явищами, предметами тощо [7, с. 194]. Г.М. Тарасова, наприклад, досліджує функціонування концепту “manus" [8, с. 433]. Так само необхідно зважати на історичну мінливість значення слів, набуття ними нових лексичних значень, мовні шляхи формування наукової термінології на основі загальновживаних слів, вплив контексту на змістовне значення слів і понять [9, с. 29-30] i, зокрема, вплив римського приватного права (наприклад: процес - processus) [10, с. 400]. С.П. Кравченко звертає увагу на стилістичну, семантичну й термінологічну «неясність правничої мови» [11, с. 60], водночас «ґрунтовні» наукові статті, присвячені проблемам лінгвістично-термінологічного дослідження текстів нормативно-правових актів і тлумачення окремих термінів і терміносполучень допомагають удосконаленню «мовного вираження» правових норм [12, с. 102].

За сучасних умов у юриспруденції правовою категорією «доктрина» оперують у різноманітних словосполученнях: позитивістська, природно-правова доктрина, юридична доктрина, доктрина абсолютного суверенітету, доктрина контролю над злочинністю, доктрина національної безпеки, доктрина правова, державно-правова доктрина, доктрина верховенства права, міжнародно-правова доктрина (або доктрина міжнародного права), доктрина глобалізації прав людини і громадянина, доктрина правової охорони довкілля, доктрина екологічного процесуального права, доктрина зайнятості тощо, що підтверджує багатоаспектність, складність, комплексність цього терміна [13, с. 8; 14, с. 5]. Науковці-правники досліджують також «зарубіжну доктрину міжнародного права» [15, с. 13].

За підсумками здійсненого нами дослідження було сформульоване визначення поняття «доктрина», яке містить серед інших ознаку - «результат певного етапу наукового пізнання певного об'єкта дійсності» [16, с. 75], отже, формування доктрини має витоки в науці [17, с. 15-16], тобто має наукове походження [18, с. 78]. Визначення саме такої ознаки $\epsilon$ в енциклопедичних визначеннях як сукупності (системи) наукових знань [19, с. 275] і в дослідженнях українських учених [20, с. 78-79; 21, с. 39; 14, с. 16]. За визначенням І.В. Семеніхіна, це своєрідний підсумок наукового пізнання [22, с. 1]. Окрім зазначеного, це: наукові праці юристів [23, с. 183]; результат проведення фундаментальних наукових досліджень; результати розвитку юридичної науки; правила, теоретичні конструкції, положення і принципи, що сформульовані юридичною наукою та мають наукову істинність; категорія наукової творчості, продукт професійної наукової діяльності [24, с. 137; 25, с. 73]; наукові розробки [26, с. 44)]; наукові доробки [27, с. 82]; одна з форм результатів наукових досліджень [14, с. 9]; категорія наукової творчості [22, с. 3]; продукт наукової діяльності, своєрідний підсумок пізнання [28, с. 27]. Загальнонаукова категорія «пізнання» водночас розуміється як набуття знань й осягнення закономірностей об'єктивного світу [29, с. 473]; як процес відображення та відтворення дійсності в мисленні, що зумовлений розвитком суспільно-історичної практики; як взаємодія об'єкта й суб'єкта, результатом якого $€$ знання про світ [30, с. 1024]; як одна з форм результатів наукових досліджень [14, с. 9]. $Є$ різні рівні пізнання: чуттєве пізнання, мислення, емпіричне й теоретичне пізнання; буденне, художнє й наукове пізнання [2, с. 489]. На підставі вищенаведеного вважаємо за необхідне ще раз звернути увагу на загальну ознаку, що $є$ притаманною для всіх понять, які позначаються 3 використанням терміна «доктрина» - всі ці поняття означають результат процесу наукового пізнання.

На думку Є. Мадаєва, доктрина може знаходити відображення в об'єктивній реальності як релігійна, політична, духовно-моральна (філософська) та правова [31, с. 63]. Щодо поняття «правова доктрина», звернемо увагу на використання терміна «науково-правова доктрина» [32, с. 98] та тверджень: «правова доктрина має наукове походження»; «це вироблені юридичною наукою положення» $[18$, с. 23, 65, 72, 77, 86]. О.Л. Копиленко та Г.О. Мурашин звертають увагу на рівень науково-правових засад [33 с. 87], В.Я. Тацій - на суспільну значущість й авторитет юридичної науки та теоретичне обґрунтування [34, с. 3], а М.Є. Мочульська зупиняє увагу на науковій обґрунтованості (достовірності) й фор- 
мально-логічній відповідності загальним вихідним принципам і закономірностям правової науки [35, с. 8]. Л.І. Чулінда досліджує питання ефективності правозастосування, зокрема вплив на неї «доктринальних досліджень» [36, с. 100]. Пізнання - це шлях, який веде від об'єкта до предмета, від первинних (чуттєвих, емпіричних) знань про право й державу до теоретичного, науково-юридичного (понятійно-правового) знання про ці об'єкти [37, с. 10].

Розуміння поняття «доктринотворення» як процесу формування доктрини взагалі та Морської доктрини України зокрема, природно, приводить до висновку, що досягнення мети дослідження передбачає виділення стадій як складників процесу доктринотворення та етапів як складників певних стадій розвитку об'єкта, що ми досліджуємо. Варто звернути увагу на той факт, що її прийняття у 2018 р. є другою «спробою» в цій сфері. Першою спробою була Постанова Кабінету Міністрів України від 7 жовтня 2009 р. № 1307 «Про затвердження Морської доктрини України на період до 2035 року» [38]. Отже, можна стверджувати те, що доктринотворення, де йдеться зокрема про Морську доктрину України, є циклічним процесом. Така сентенція може бути підтверджена наявністю декількох подібних спроб в інших сферах. Наприклад: перша редакція Воєнної доктрини України була прийнята Постановою Верховної Ради України № 3529-XII 19 жовтня 1993 року [39]; друга - Указом Президента України № 648/2004 15 червня 2004 року [40]; третя прийнята Радою національної безпеки й оборони України (далі - РНБО України) 2 вересня 2015 року [41] і введена в дію Указом Президента України 24 вересня 2015 року [42]. Необхідно додати, що 14 березня 2016 року Указом Президента України [43] було введено в дію рішення Ради національної безпеки й оборони України від 04 березня 2016 року «Про концепцію розвитку сектору безпеки й оборони України» [44]. Отже, поділяючи доктринотворення на певні стадії та етапи, ми говоримо про циклічність досліджуваного процесу розвитку.

Першою стадією цього процесу варто визначити «стадію розвитку витоків (джерел, підстав) доктринотворення». Зазвичай, але не щодо доктринотворення, науковці визначають цю стадію як «матеріальну» [45, с. 469; 46, с. 204] - стадію розвитку матеріальних витоків (джерел, підстав) об'єктивну (природно-історичну) стадію, яка пов'язана з розвитком суспільного буття. Складниками цієї стадії можна назвати певні етапи, наприклад: етап розвитку нових видів діяльності в певних сферах суспільного виробництва; етап розвитку нових технологій, методів, способів суспільного виробництва; етап розвитку нових суспільних відносин; появу певних правових актів - юридичних фактів - обставин об'єктивного суспільного життя, які стали підставою виникнення відповідних правовідносин тощо.

Необхідно зауважити, що саме з появою відповідних правових актів пов'язана підзаконна діяльність Кабінету Міністрів України з формування Морської доктрини України. Так, підставою для формування Морської доктрини 2009 р. став Указ Президента України № 463/2008 від 20 травня 2008 р. [47], яким було введено в дію рішення РНБО України від 16 травня 2008 р. «Про заходи щодо забезпечення розвитку України як морської держави» [48]. Відповідно підставою для формування Морської доктрини редакції 2018 р. стали: Указ Президента України № 287/2015 від 26 травня 2015 р. [49], яким було введено в дію рішення РНБО України від 06 травня 2015 р. «Про стратегію національної безпеки України» [50] (до речі, вимога про затвердження нової редакції Морської доктрини України «у тримісячний строк» виконана не була!), та Указ Президента України від 12 жовтня 2018 року № 320/2018 [51], яким було введено в дію рішення РНБО України від 12 жовтня 2018 року «Про невідкладні заходи щодо захисту національних інтересів на Півдні та Сході України, а також Чорному та Азовському морях і Керченській протоці» [52].

Друга стадія - «стадія наукового пізнання». Зазвичай, але не щодо доктринотворення, науковці визначають цю стадію як «гносеологічну» [45, с. 469; 46, с. 204] - суб'єктивну стадію, яка пов' язана з пізнавальною діяльністю суб'єктів, які долучаються самостійно (як суб'єкти професійної та/або наукової діяльності), за планами наукової діяльності або на запит компетентних державних органів (як суб'єкти наукової діяльності в певній сфері) до пізнання явищ суспільного буття в певній сфері. Складниками цієї стадії (не визначаючи за мету дослідження саме процес наукового пізнання) варто, на нашу думку, виділити: етап вивчення проявів (явищ) суспільного буття (для правових доктрин - проявів (явищ) державно-правової дійсності; етап виявлення фактів, тенденцій, характеристик і проблем, які стосується певних проявів (явищ) суспільного буття (буденне пізнання); етап визначення об'єкта, предмета, методів і цілей дослідження; етап аналізу інформації: статистичної, аналітичної, емпіричної тощо, 
яка пов'язана з вивченням обраного предмета дослідження; етап виявлення внутрішніх та зовнішніх чинників, які мають вплив (позитивний або негативний) на розвиток об'єкта дослідження; етап опрацювання й формулювання висновків і пропозицій, котрі стосуються розвитку об'єкта дослідження; етап об'єктивації (документування) результатів дослідження.

Проходження «стадії наукового пізнання» (етапів цієї стадії) характеризується розвитком (виникненням і трансформацією) певних якісних ознак, які характеризують, зокрема, суб'єктів пізнання. Отже, аналізуючи проходження цієї стадії, варто звернути увагу на таке.

1. Можна казати про розвиток на цій стадії «уявлення», розуміючи це поняття як: форму почуттів, відображену у вигляді наочно-образного знання; образ, який був створений уявленням раніше сприйнятого предмета або явища; погляди або судження, котрі виявляють відношення до предмета або явища, зазвичай із психологічними станами сумнівів, знань, переконаності або віри [29, с. 305, 676; 2, с. 506, 635]; розумовий акт, який реалізує ставлення суб'єкта до змісту твердження та який $є$ пов'язаним із переконаністю або сумнівами щодо його істинності або помилковості [30, с. 1288]. Звідси можна зробити висновок про помилковість твердження про те, що «доктрина» - це, зокрема: система уявлень, поглядів [53, с. 293; 54, с. 19]; система наукових поглядів [18, с. 72; 25, с.73]; погляди вчених, учених-юристів, представників юридичної науки [55, с. 385 , 456; 9, с. 141]; думка учених [56, с. 123]; доктринальне бачення [57, с.106]; доктринальні погляди [58, с. 26].

Щодо розвитку «ідей», розуміючи це поняття як форму осягнення в думці явищ об'єктивної реальності, то в науці «ідеї» слугують основою, яка синтезує знання в цілісну систему, виконують роль принципів пояснення явищ [2, с. 207]; уявлення, що відображає дійсність у свідомості людини, яке породжує його ставлення до неї; засаднича, головна думка; задум, що визначає зміст будь-чого; план [29, с. 205]; форма відображення в думці явищ об'єктивної реальності; осягаючи дійсність, «ідея» містить у собі уявлення про мету подальшого пізнання і практичного перетворення світу. «Ідеї» узагальнюють досвід попереднього розвитку знання та слугують принципом пояснення явищ дійсності [30, с. 476]. Отже, варто сказати про помилковість тверджень про те, що «доктрина» це, зокрема: уявлення, погляди або система концептуально-оформлених ідей [59, с. 85]; система наукових ідей [20, с. 82].

2. На цій стадії (на певному їі етапі) визначаються об'єкт, предмет і мета дослідження. «Об'єкт» - це те, що протистоїть суб'єкту в його предметно-практичній і пізнавальній діяльності. Виділення об'єкта пізнання здійснюється за допомогою форм практичної й пізнавальної діяльності, що є опрацьованими суспільством, які відображають властивості об'єктивної реальності [2, с. 437-438]. Об'єкт пізнання юридичної науки взагалі та загальнотеоретичної юриспруденції як юридичної науки, зокрема - це: право [60, с. 52; 61, с. $25 ; 62$, с. 71; 63, с. 401]; правові норми [64, с. 120]; стратегічні перспективи правового розвитку держави [65, с. 101]; правова система держави [66, с. 311]; право, правова система $[67$, с. 179,180$]$; правові явища [23, с. 65, 183; 19, с. 275; 68, с. 201]; правова система; правові явища; правова матерія; правова дійсність [18, с. 6, с.28, с. 34]; держава і право [69, с. 3-4; 70 , с. $321 ; 71$, с. $457 ; 72$, с. $189 ; 46$, с. $3 ; 73$, с. 11]; державно-правові явища [74, с. 19-20; 75, с. 187]; державно-правова дійсність, державні та правові явища [76, с. 9]; держава і право, державно-правові явища [77, с. 6]; державно-правова дійсність [78, с. 92]; держава та право; державно-правові явища; державно-правова дійсність [37, с. 8, 11; 79, с. 3]; державно-правова реальність; державно-правові явища [80, с. 7-8]; державно-правова дійсність; державно-правові явища i процеси [28, с. 27, 34]. Найбільш удалим, з огляду на загальність (за загальнотеоретичною спрямованістю) та об'ємність (за змістом), здається визнання «державно-правової дійсності» об'єктом пізнання юридичної науки взагалі та загальнотеоретичної юриспруденції як галузі юридичної науки, зокрема. Об'єктом правової (морської) доктрини $\epsilon$ визначення та вирішення питань розвитку (виникнення, трансформації, зникнення) проявів державно-правової дійсності у сфері морської діяльності [16, с. 75].

«Предмет» - це категорія, що визначає певну цілісність, яку було виділено з певної кількісті об'єктів у процесі людської діяльності та пізнання. Той самий об'єкт може бути предметом різних видів дослідження. Базовою структурною відмінністю предмета та об'єкта $є$ те, що до предмета належать лише головні, найбільш суттєві (на думку дослідника) відмінності та ознаки [2, с. 505]. Кожна наука має свої об’єкт і предмет дослідження. Об'єкт - це ті явища, котрі вивчаються наукою, предмет - це те, що цікавить науку 
в конкретному об'єкті [37, с. 10]. Щодо предмета пізнання юридичних наук - це: «предмет общей теории права и государства - это общая теория всей юриспруденции в качестве единой самостоятельной и системно целостной науки» [55, с. 3]; державно-правові проблеми різного рівня узагальнення [81, с. 27]; держава і право як специфічні суспільні явища, загальні закономірності їх виникнення, призначення й функціонування, їх сутність, типи, форми, функції, структура й механізм дії, відносини з іншими суб'єктами суспільного життя, основні державно-правові категорії, спільні для всіх галузей юриспруденції, а також особливості державно-політичної і правової свідомості та правової культури [37, с. 23]; програмнодекларативні політичні настанови, що визначають суспільний статус, мета розвитку, принципи організації, роль української науки у становленні нової України [82, с. 19]; певна модель правового регулювання в конкретному державно-правовому просторі; основні закономірності (й випадковості) становлення, оформлення, функціонування права й держави, через які розкриваються об'єктивні властивості право-державних явищ i процесів [46, с. 3, 5]; «в самом общем виде предмет общетеоритической юриспруденции - это формирование, разработка и конкретизация общего понятия права и государства; особое постижение сложного объекта, в качестве которого выступают право и государство; постижение закономерностей и случайностей возникновения, развития и функционирования права и государства, их роли в различных цивилизациях и культурах [73, с. 11-12]; суспільні відносини [83, с. 415]. Предметом правової (морської) доктрини $\epsilon$ правове регулювання суспільних («особа-техніка», «особа-довкілля») та соціальних («особа-особа») відносин, які виникають у цій сфері (предмет пізнання в межах об'єкта пізнання - державно-правової дійсності) [16, c. 75].

Метою затвердження Морської доктрини України на період до 2035 року (як редакції 2009 р., так і 2018) було «визначення стратегії та основних напрямів подальшого розвитку України як морської держави".

3. На певних етапах цієї стадії формуються теорії та вчення. «Теорія» - це вища, найбільш розвинута форма наукового знання, яка надає цілісне уявлення про закономірності та суттєві зв'язки визначеної області дійсності - об'єкта цієї теорії [30, с. 1322; 2, с.649]; це система наукових принципів, які узагальнюють практичний досвід і відображають закономірності природи, суспільства, пізнання; сукупність узагальнюючих положень, які формують науку або розділ науки $[29$, с. 689]. Наведемо визначення поняття, що охоплюється терміном «парадигма - це теорія (модель постановки проблем), яка приймається як зразок рішення дослідницьких завдань [2, с. 460].

Доцільно навести також визначення понять, що охоплюються термінами «категорія», «концепція», «принцип». «Категоріями» називаються найбільш загальні поняття. В них віддзеркалюється державно-правова дійсність, міститься теоретично узагальнена за змістом і коротка за формою викладу відповідь на питання, чим $\epsilon$ те або інше державно-правове явище, що характеризує державу і право загалом [37, с. 19]. «Концепція» - це: певний спосіб розуміння, тлумачення якогось предмета, явища, процесу як підґрунтя для їх систематичного висвітлення; керівна ідея, провідна задумка, конструктивні принципи певного виду діяльності [2, с. 279]; це система поглядів на будь-що, головна думка [29, с. 252]; певний спосіб розуміння, трактування певних явищ; конструктивний принцип різних видів діяльності. «Принцип» - це основне, вихідне положення певної теорії, вчення, науки [30, с. 625, 1061]. «Вчення»це: сукупність теоретичних положень про певну область явищ дійсності [29, с. 734; 30, с. 1396].

Щодо ознак поняття «доктрина» - це: система наукових теорій [20, с. 82]; теорія, наука [84, с. 170-171]; науково-теоретичні доктринальні положення [55, с. 385,$456 ; 85$, с. 195]; система принципів [54, с. 19]; це вироблені юридичною наукою положення [18, с. 23-29, 65, 66, 72-77, 86] щодо ознак поняття «правова доктрина». На наш погляд, такі твердження щодо понять «доктрина», «правова доктрина», «правова (морська) доктрина», «Морська доктрина України» будуть коректними тільки після завершення «стадії суспільної доктриналізації» та «стадії державної доктриналізації» (про що дивись далі).

4. Етап об'єктивації (документування). Формами об'єктивації правової доктрини визнаються: наукові праці юристів; праці вчених-юристів [56, с. $123 ; 23$, с. 65]; доктринальні тексти найбільш відомих юристів [81, с. 27-28]; наукові праці в галузі права [61, с. 25]; зазвичай, це акт-документ або документ [46, с. 221; 65], який об'єктивується в письмовій і змішаній (письмовій та усній) формі $[14$, с. 16]; безпосередньо оформлюється у вигляді наукових праць із питань права - монографій, наукових статей, коментарів до законодавства тощо [28, с. 27]; це праці вчених-правників; формально виражені в побуто- 
вому сенсі (тобто викладені на папері чи в електронний ресурс), а не у правовому сенсі, тобто визначені в законі; документально оформлені $[67$, с. 178,179$]$.

Третя стадія - «стадія суспільної доктриналізації» - стадія визнання результатів дослідження науковою спільнотою. Етапами цієї стадії визначимо: етап оприлюднення, обговорення, апробації результатів дослідження; етап прийняття рішення щодо юридизації результатів дослідження та звернення до компетентних органів державної влади та/або суб'єктів права законодавчої ініціативи (формування «юридичного мотиву»).

Метою оприлюднення доктринальних положень $\epsilon$ потрібність певного часу для сприйняття та осмислення фахівцями-практиками та науковцями. Зазвичай норми, що не сприймаються суспільством та фахівцями, приречені на коротке життя; вони мають пройти випробування часом та набрати необхідний авторитет серед науковців [66, с. 304]. Наукова дискусія може тривати роками на сторінках журналів, наукових конференціях, «круглих столах» тощо [28, с. 29]. Водночас особливо відповідальним для вчених-правознавців $\epsilon$ професійна позиція, заявлена науковцем або колективом авторів на власну доктринальну теорію в певному напрямі (галузі) знань [68, с. 201]; офіційна апробація [65; 66, с. 304].

Правова доктрина має бути визнана: юридичною спільнотою; юридичною (насамперед академічною) спільнотою [86, с. $120 ; 18$, с. 6 ; 14, с. 15; 28, c. 34]. Правова доктрина - це система панівних (визнаних юридичною спільнотою) юридико-пізнавальних форм трактування права [81, с. 27-28], яка усвідомлена (сприйнята) суспільством і підтримується (формалізується) державою [46, с. 221; 65]; отримала визнання суспільством, серед учених та з боку держави [87, с. 71]; визнана суспільством [67, с. 179-180].

Підставою загального визнання наукових положень, набуття ними статусу доктринальних $\epsilon$ : переконливість, логічна обґрунтованість, наукова істинність; методологічний плюралізм, справжня наукова дискусія, вільний обмін думками. Сьогодні свобода наукової творчості, автономність і незалежність академічної спільноти, так званий «вільний ринок ідей» - загальновизнані й беззаперечні цінності та принципи західного світу [22, c. 7].

Четверта стадія - «стадія державної доктриналізації» - стадія юридизації результатів дослідження - стадія надання певній доктрині статусу джерела права у формі правового акта. Ця стадія містить етапи державного визнання на рівні компетентних органів виконавчої влади та етапи державного визнання на рівні законодавчої влади. Морська доктрина у редакції 2009 та 2018 років дістала офіційного державного визнання на рівні Кабінету Міністрів України.

Висновки. Вищезазначене дало підстави 1) сформулювати визначення понять, які означені термінами: «доктринотворення» - це процес формування певної доктрини; «доктриналізація» - це стадія доктринотворення, яка складається зі «стадії суспільної доктриналізації» - стадії визнання результатів дослідження науковою спільнотою, та «стадії державної доктриналізації» - стадія юридизації результатів дослідження - стадії надання певній доктрині статусу джерела права у формі правового акта. 2). Визначити чотири стадії доктринотворення та етапи відповідних стадій. 3). Визначити, що підставами формування Морської доктрини України на період до 2035 року $\epsilon$ набрання чинності відповідними правовими актами. 4). Визначити процес формування Морської доктрини України на період до 2015 року як процес розвитку, що має циклічний характер, а метою іiі затвердження $\epsilon$ визначення стратегії та основних напрямів подальшого розвитку України як морської держави.

\section{Література}

1. Про внесення змін до Морської доктрини України на період до 2035 року : Постанова Кабінету Міністрів України від 18.12.2018 р. № 1108. Офіційний вісник України. 2019. № 2. Ст. 53.

2. Философский энциклопедический словарь / редкол.: С.С. Аверинцев, Э.А. Араб-Оглы, Л.Ф. Ильичев и др. 2-е изд. Москва : Сов. энциклопедия, 1989. 815 c.

3. Краткий словарь по социологии / под общ. ред. Д.М. Гвишиани, Н.И. Лапина; сост. Э.М. Коржева, Н.Ф. Наумова. М.: Политиздат, 1989. 479 с.

4. Логіка: підручник / В.Д. Титов, С.Д. Цалін, О.П. Невельська-Гордєєва та ін. ; за заг. ред. В.Д. Титова. Харків : Право, 2005. 208 с.

5. Верба Л.Г. Порівняльна лексикологія англійської й української мов. Вінниця : Нова книга, 2008. 248 c.

6. Сога Л.В. Полісемія як мовна універсалія в системі європейських мов. Науковий огляд. 2016. № 4(25). С. 1-14.

7. Кочерган М.П. Вступ до мовознавства: підручник. Київ : ВЦ «Академія», 2008. 368 с.

8. Тарасова Г.М. Функціонування концепту "manus" в юридичному та інших видах дискурсу. Правове життя сучасної України: матеріали Міжнар. 
наук.-практ. конф. (м. Одеса, 15 трав. 2020 р.). Одеса : ВД «Гельветика», 2020. Т. 2. С. 432-434.

9. Пархоменко Н.М. Джерела права: проблеми теорії та методології. Київ : Юрид. думка, 2008. 336 с.

10. Дихта Н.М. Вплив римського приватного права на формування та існування юридичної термінології на прикладі сучасних англо-українських словників. Правове життя сучасної України: матеріали Міжнар. наук.-практ. конф. (м. Одеса, 15 трав. 2020 р.). Одеса : ВД «Гельветика», 2020. Т. 2. С. 400-402.

11. Кравченко С.П. Лінгвістичні особливості юридичного дискурсу. Правове життя сучасної України: матеріали Міжнар. наук.-практ. конф. (м. Одеса, 15 трав. 2020 р.). Одеса : ВД «Гельветика», 2020. Т. 1. С. 58-60.

12. Чулінда Л.І. Юридико-лінгвістичне тлумачення текстів нормативно-правових актів. Київ : Атіка, 2005. 200 c.

13. Тодика О.Ю. Народовладдя на трансформаційному етапі розвитку держави і суспільства. Харків : Право, 2007. 480 с.

14. Анісімова Г.В. (2016). Інтеграція природноправової доктрини до еколого-правової науки, доктрини, політики й законодавства: деякі аспекти. Теорія і практика правознавства. 2016. Вип. 1(9). С. 1-20.

15. Андрейченко С.С. Питання міжнародної відповідальності держава в зарубіжній доктрині міжнародного права XVI - XIX ст. ст. Правове життя сучасної України: матеріали Міжнар. наук.-практ. конф. (м. Одеса, 15трав. 2020р.). Одеса: ВД «Гельветика», 2020. Т. 3. С. 13-16.

16. Кузнєцов С.С. Морська доктрина України: вимір загальнотеоретичної юриспруденції. Правова держава. 2020. № 37. С. 71-78. https://doi.org/10.18 524/2411-2054.2020.37.201504.

17. Спасибо-Фатєєва І.В. Доктринальне тлумачення. Вісник Академії правових наук України. 2005. № 1(40). С. 14-24.

18. Семеніхін І.В. Правова доктрина: загальнотеоретичний аналіз. Харків : Юрайт, 2012. 88 с.

19. Юридична енциклопедія: в 6 т. / редкол.: Шемшученко Ю.С. та ін. Київ : Укр. енцикл., 1998. Т. 2: Д-Й, 2003. 744 с.

20. Євграфова Є.П. Доктрини та концепції у правовій системі України: форми і сфери застосування. Право України. 2010. № 5. С. 77-84.

21. Мочульська М.Є. Правова доктрина та правова наука: співвідношення понять. Проблеми державотворення і захисту прав людини в Україні: матеріали XVIII регіон. наук.-практ. конф. (26-27 січ.
2012 р.). Львів : Львів. нац. ун-т ім. І. Франка, 2012. С. 39-41.

22. Семеніхін І.В. Правова доктрина, наукова спільнота та влада: окремі питання співвідношення та взаємодії. Теорія і практика правознавства. Вип. 1(9). С. 1-14.

23. Вавилин Є.В. Некоторые проблемы механизма защиты субъективных гражданских прав. Правоведение. 2002. № 3(242). С. 178-185.

24. Пузиков Р.В. Сущность юридической доктрины как источника права. Правовая политика и правовая жизнь. 2003. № 4. С. 133-138.

25. Пузиков Р.В. Юридическая доктрина в сфере правового регулирования (проблемы теории и практики) : дис. ... канд. юрид. наук. Тамбов, 2003. 213 с.

26. Зеленкевич И.С. Правовая доктрина и правовая наука: некоторые аспекты соотношения и использования в качестве источников права. Северо-Восточный научный журнал. 2010. № 2(6). С. 42-47.

27. Ковальський В.С., Козінцев І.П. Правотворчість: теоретичні та логічні засади. Київ : Юрінком Інтер, 2005. 192 c.

28. Семеніхін І.В. Правова доктрина: поняття, ознаки, структура. Проблеми законності. 2016. Вип. 132. С. 26-36.

29. Ожегов С.И. Словарь русского языка / под ред. чл.-корр. АН СССР Н.Ю. Шведовой. 18-е изд., стереотип. Москва : Рус. яз., 1987. 797 с.

30. Советский энциклопедический словарь / гл. ред. А.М. Прохоров; редкол.: А.А. Гусев и др. изд. 4-е. Москва : Сов. энциклопедия, 1986. 1600 с.

31. Мадаев Е.О. Доктрина в правовой системе Российской Федерации: дис. ... канд. юрид. наук : 12.00.01. Иркутск, 2012. 254 с.

32. Андрейцев В.І. Правова доктрина України: монографія: у 5 т. / Ю.С. Шемшученко, А.П. Гетьман, В.І. Андрейцев та ін. ; за заг. ред. Ю.С. Шемшученко. Т. 4: Доктринальні проблеми екологічного, аграрного та господарського права. Харків : Право, 2013. 848 c.

33. Копиленко О.Л., Мурашин Г.О. Деякі методологічні аспекти наукового забезпечення законодавчого процесу. Методологічні проблеми правової науки: матеріали Міжнар. наук. конф. (М. Харків, 13 -14 груд. 2002 р.). Харків : Право, 2003. С. 132-142.

34. Тацій В.Я. Методологічні проблеми правової науки на етапі формування правової, демократичної, соціальної держави. Методологічні проблеми правової науки: матеріали міжнар. наук. конф. (м. Харків, 13-14 груд. 2002 р. ). Харків : Право, 2003. С. 3-13.

35. Мочульська М.Є. Правова доктрина в континентальній правовій системі : автореф. дис. ... канд. 
юрид. наук : 12.00.01. Львів. нац. ун-т ім. І. Франка. Львів, 2011. 19 с.

36. Чулінда Л.І. Вплив доктринальних досліджень на ефективність правозастосування. Правове життя сучасної України: матеріали Міжнар. наук. практ. конф. (м. Одеса, 15 трав. 2020 р.). Одеса : ВД «Гельветика», 2020. Т. 1. С. 100-103.

37. Копиленко О.Л. Теорія держави і права в системі юридичних наук. Теорія держави і права. Академічний курс: підручник / за заг. ред. О.В. Зайчука, Н.М. Оніщенко. Київ : Юрінком Інтер, 2006. 688 с.

38. Про затвердження Морської доктрини України на період до 2035 року : Постанова Кабінету Міністрів України від 7.10.2009p. № 1307. Офіційний вісник України. 2009. № 94. Ст. 3216.

39. Про Воєнну доктрину України: Постанова Верховної Ради України від 19.10.1993р. № 3529-XII. Відомості Верховної Ради України. 1993. № 43. Ст. 409 (утр. чин.).

40. Про Воєнну доктрину України: Указ Президента України від 15.06.2004 р. № 648/2004. Офіційний вісник України. 2004. № 30 Ст. 2005.

41. Про нову редакцію Воєнної доктрини України : рішення Ради національної безпеки й оборони України 2.09.2015 р. Офіційний вісник України. 2015. № 78. Ст. 2592.

42. Про рішення Ради національної безпеки i оборони України від 2 вересня 2015 року «Про нову редакцію Воєнної доктрини України» : Указ Президента України 24.09.2015 р. № 555/2015. Офіційний вісник України. 2015. № 78. Ст. 2592.

43. Про рішення Ради національної безпеки і оборони України від 4 березня 2016 року «Про Концепцію розвитку сектору безпеки і оборони України» : Указ Президента України від 14.03.2016 р. № 92/2016. Офіційний вісник України. 2016. № 23. Ст. 898.

44. Про концепцію розвитку сектору безпеки i оборони України : рішення Ради національної безпеки і оборони України від 04.03.2016 р. Офіційний вісник України. 2016. № 23. Ст. 898.

45. Скакун О.Ф. Теория государства и права (энциклопедический курс). Харків : Эспада, 2005. 840 c.

46. Скакун О.Ф. Теорія права і держави. Київ : Алерта; КНТ; ЦУЛ, 2009. 520 с.

47. Про рішення Ради національної безпеки і оборони України від 16 травня 2008 року «Про заходи щодо забезпечення розвитку України як морської держави» : Указ Президента України від 20.05.2008 р. № 463/2008. Офіційний вісник України. 2008. № 38. Ст. 1265 (утр. чин.).

48. Про заходи щодо забезпечення розвитку України як морської держави : Рішення РНБО Украї- ни від 16.05.2008 р. Офіційний вісник України. 2008. № 38. Ст. 1265 (утр. чин.).

49. Про рішення Ради національної безпеки і оборони України від 06 травня 2015 року «Про стратегію національної безпеки України» : Указ Президента України від 26.05.2015 р. № 287/2015. Офіційний вісник України. 2015. № 43. Ст. 1353.

50. Про стратегію національної безпеки України: рішення Ради національної безпеки і оборони України від 06.05.2015 р. Офіційний вісник України. 2015. № 43. Ст. 1353.

51. Про рішення Ради національної безпеки і оборони України від 12 жовтня 2018 року «Про невідкладні заходи щодо захисту національних інтересів на Півдні та Сході України, і Чорному та Азовському морях і Керченській протоці» : Указ Президента України від 12.10.2018 р. № 320/2018. Офіційний вісник Президента України. 2018. № 24. Ст. 456.

52. Про невідкладні заходи щодо захисту національних інтересів на Півдні та Сході України, і Чорному та Азовському морях і Керченській протоці : рішення Ради національної безпеки і оборони України від 12.10.2018 р. Офіційний вісник Президента України. 2018. № 24. Ст. 456.

53. Тихомиров Л.В., Тихомиров М.В. Юридическая энциклопедия. Москва : Изд-во М.Ю. Тихомирова, 2005. 472 с.

54. Васильев А.О. Правовая доктрина как источник права: историко-теоретические вопроси : дис. ... канд. юрид. Наук : 12.0001. Барнаул, 2007. 192 с.

55. Нерсесянц В.С. Общая теория права и государства. Москва : ИНФРА-М, 1999. 552 с.

56. Волинка К.Г. Теорія держави і права: навч. посіб. Київ : МАУП, 2003. 240 с.

57. Крижанівський А.Ф. Правовий порядок в Україні: витоки, концептуальні засади, інфраструктура: монографія. Одеса : Фенікс, 2009. 504 с.

58. Бєлогубова 0.0. Доктринальні погляди на відокремлення міжнародного приватного трудового права. Правове життя сучасної України: матеріали Міжнар. наук.-практ. конф. (м. Одеса, 15 трав. 2020 р.).Одеса : ВД «Гельветика», 2020. T. 3. С. 26-28.

59. Трофименко В.А. Правова доктрина - основа формування правової системи країни. Вісник Національної юридичної академії України імені Ярослава Мудрого. Серія: Філософія права, політологія, соціологія. 2009. № 2. С. 85-95.

60. Лазарев Л.В. Правовые позиции Конституционного Суда России. Москва : Формула права, 2008. 688 c.

61. Гаврюсов Ю.В. Правовая природа решений органов конституционною юстиции. Вестник 
Калининградского юридического института МВД России. 2009. № 2(18). С. 24-30.

62. Васильєв С.В. Правова доктрина - джерело процесуального права. Актуальні питання інноваційного розвитку. 2012. № 2. С. 70-76.

63. Нерсесянц В.С. Общая теория государства и права. Москва : ИНФРА-М, 2012. 560 с.

64. Христова Г.О. Загальна теорія держави і права / за ред. М.В. Цвіка, В.Д. Ткаченка, О.В. Петришина. Харків : 2002. 583 с.

65. Кармаліта М.В. Правова доктрина - джерело (форма) права : дис. ... канд. юрид. наук : 12.00.01. Київ, 2011. 199 с.

66. Полянський Є.Ю. Правова доктрина як базисна концепція права. Наукові праці Національного університету «Одеська юридична академія». 2015. C. 297-313.

67. Іскра С. Визначення правової доктрини у співвідношенні з юридичною наукою. Підприємництво, господарство і право. 2018. № 11. С. 177-180.

68. Щербанюк О., Гріненко О. Правові доктрини як фундамент розвитку юридичної науки Право України. 2015. № 9. С. 201-203.

69. Недбайло П.Є. Введение в общую теорию государства и права (предмет, система и функции науки). Київ : Вища шк., 1971160 с.

70. Рабінович П.М. Основи загальної теорії права та держави. Київ : Навчальне видання, 1994. 267 с.

71. Рабінович П.М. Загальна теорія держави і права. Юридична енциклопедія: в 6 m. Т. 2: Д-Й / редкол.: Шемшученко Ю.С. та ін. Київ : Укр. енцикл., 1999.

72. Гусарєв С.Д., Тихомиров О.Д. Юридична деонтологія. Основи юридичної діяльності: навч. посіб. Київ : Знання, 2008. 495 с.

73. Оборотов Ю.М. Общетеоретическая юриспруденция. Одеса : Фенікс, 2011. 436 с.

74. Хропанюк В.М. Теория государства и права. Москва : Интерстиль, 2001. 380 с.

75. Комаров, С.О., Малько О.В. Теория государства и права. Москва : НОРМА, 2003. 365 с.

76. Общая теория государства и права: акад. курс в 2 т. / под.ред. Марченко М.Н., соавт.: Керимов Д.А., Мицкевич А.В. Т.1. Теория государства. Москва : Зерцало, 1998. 408 с.
77. Комаров С.А. Общая теория государства и права. Санкт-Петербург : Юристъ, 2001. 450 с.

78. Козюбра М.І. Наукознавчі проблеми загальної теорії держави і права. Методологічні проблеми правової науки: матеріали Міжнар. наук. конф. (Харків, 13-14 груд. 2002 р.). Харків : Право, 2003. С. 91-94.

79. Шемшученко Ю.С. Теорія держави і права. Академічний курс: підручник / за заг. ред. О.В. Зайчука, Н.М. Оніщенко. Київ : Юрінком Інтер, 2006. 688 c.

80. Тацій В.Я., Петрішин О.В. Передмова. Правова система України: історія, стан та перспективи: у 5 т. / Т. 1: Методологічні та історико-теоретичні проблеми формування і розвитку правової системи України / за заг. ред. М.В. Цвіка, О.В. Петришина. Харків : Право, 2008.

81. Зозуля 0.0. Доктрина в современном праве : дис. ... канд. юрид. Наук : 12.00.01. СПб., 2006. $232 \mathrm{c}$.

82. Маліцький Б.А. Сучасний стан наукової сфери України та нова стратегічна доктрина їі розвитку. Наука та наукознавство. 2006. № 2. С. 16-32.

83. Поляков А.В. Юридическая наука, практика, политика. Lex russica. 2014. № 4. С. 413-420.

84. Рудницький Я.Б. Етимологічний словник української мови : в 2 т. Т. ІІ: Д-ь. Оттава : Укр. Могилян.-Мазепин. акад. наук,1982. 1128 с.

85. Правовая система Республики Беларусь: состояние, проблемы и перспективы развития: материалы IX межвузовской научной конференции студентов, магистрантов и аспирантов (Гродно, 9 апр. 2009 г.) / ред. кол.: И.В. Гущин и др. Гродно : ГрГУ, 2009. 395 с.

86. Цвік М.В. Загальна теорія держави і права / за ред. М.В. Цвіка, В.Д. Ткаченка, О.В. Петрішіна. Харків, 2002. 583 с.

87. Бошно С. Доктрина как форма и источник права. Журнал российского права. 2003. № 12. C. 70-79.

Кузнєчов С. С., кандидат політичних наук, директор Навчального чентру фахівців морського транспорту 